\section{Electromagnetic Fields of Mobile Phone Jammer Exposure on Blood Factors in Rats}

\author{
Shojaeifard M.B., ${ }^{1,2 *}$, Jarideh S. ${ }^{2}$, Owjfard M. ${ }^{2}$, Nematollahii \\ S. ${ }^{3}$, Talaei-Khozani T. ${ }^{4}$, Malekzadeh M. ${ }^{2}$
}

\begin{abstract}
Background: The increasing demand for using mobile phones has led to increasing mobile phone jammers as well. On the other hand, reports show that exposure to electromagnetic field causes an increase in the incidence of diseases such as leukemia, cancer, depression and failure in pregnancy outcomes; therefore, the aim of this study is to investigate the effects of exposure to electromagnetic fields of mobile phone jammers on blood factors.

Materials and Methods: Thirty male Wistar immature and thirty mature rats were selected randomly and each one was divided into three groups of ten. The control group did not receive any radiation; the sham group was exposed to a switchedoff jammer device and the experimental group was exposed to electromagnetic fields (EMF) radiated by Mobile Phone Jammer daily eight hours for five days a week during forty days. Blood sample was taken from heart and blood factors including PLT, MCHC and RDWCV were measured. The data were analyzed by ANOVA which was followed by Duncan's test.

Results: The data from mature rats revealed that jammer usage led to a significant difference in blood factors including RBC, platelet, hemoglobin, hematocrit, $\mathrm{MCV}$ and RDWCV $(\mathrm{P} \leq 0.05)$; however, the number of lymphocytes, WBC and MCVH in the blood was the same in all groups. In immature rats, the exposure to jammer did not change RBC, lymphocyte and WBC count, hemoglobin and hematocrit; while, the platelet count along with MCHC, MVC and RDWCV changed by jammer radiation.
\end{abstract}

Conclusion: The results exhibited that mobile phone jammer caused frequent changes in blood cell factors.

\section{Keywords}

Electromagnetic Field (EMF), Radiation, Mobile Phone Jammer, Blood Cell Factors

\section{Introduction}

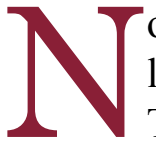
on-Ionizing radiation (NIR) is radiant energy with long wavelengths more than $100 \mathrm{~nm}$ and low- energy photons $(12.4 \mathrm{eV})$. These rays appear on the electromagnetic field (EMF) spectrum. EMF wavelength is between $1 \mathrm{~Hz}$ to $3 \times 10^{15} \mathrm{~Hz}$. EMF contains the microwave, very high frequency and low frequency radio waves; these are called radiofrequency waves as well. NIR hits tissues, and generates heat. The absorption characteristics of the radiation in different body tissues are dependent on the penetration, duration of exposure and
${ }^{1}$ Physiology Department, Fasa University of Medical Sciences, Fasa, Iran

${ }^{2}$ Ionizing and Non-ioniz-

ing Radiation Protection

Research Center (INIR-

PRC), Shiraz University

of Medical Sciences,

Shiraz, Iran

${ }^{3}$ Biostatistic Depart-

ment, Shiraz University

of Medical Sciences,

Shiraz, Iran

${ }^{4}$ Anatomy Department,

Medical School, Shiraz

University of Medical Sci-

ences, Shiraz, Iran

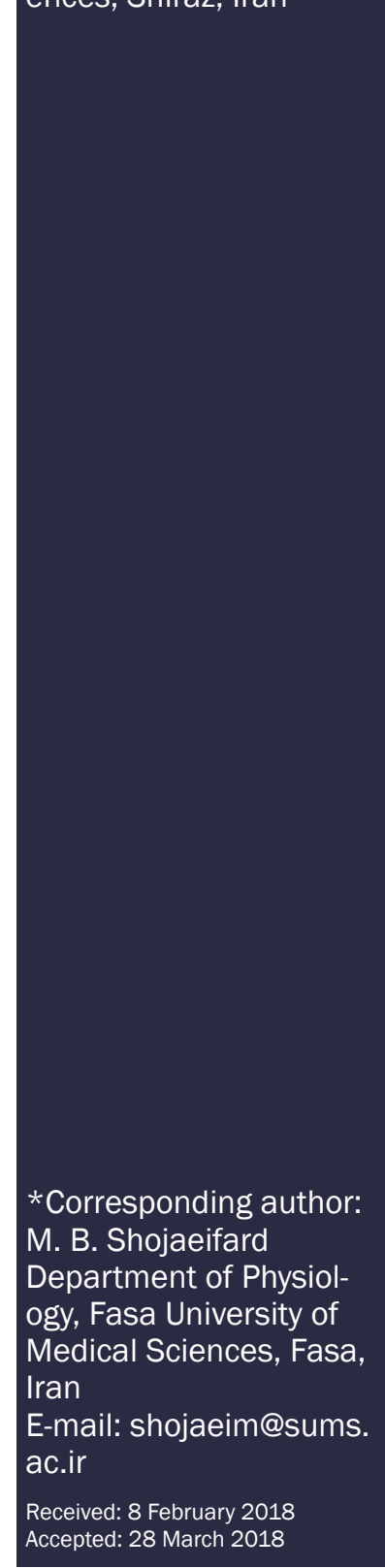


biological properties of the irradiated tissues [1]. One application of EMF is telecommunication. Nowadays, cell phones have a wide use in society but they have caused problems related to disturb people or community security. Therefore, one of the ways to stop this disruption is using jammer devices. Mobile Jammer device uses radio waves radiation with the same frequency of global system mobile (GSM) to prevent from receiving signals of base station by cellular phones. Cell phones work through base stations with their service networks. When jamming is effective, the jammer power will be equal to the signal power at the receiver. A jammer device usually emits radiation and people who attend those places expose to it [2].

Studies have shown that electromagnetic fields emitted by mobile phones cause disorders in learning, memory [3], sleep patterns [4] and disturbance in neurotransmitter release [5], blood-brain barriers [6] and also led to cancers and other diseases [7-8]. Electromagnetic fields emitted by mobile phones may change the content of the reactive oxygen species (ROS) in cells [9]. Moreover, a few studies showed that cell phones radiation interfered with endocrine system and changed the level of some hormones in serum [10] such as progesterone [11] or thyroid hormones [12].

The aim of the current study is to investigate the impact of radiation emitted of mobile phone jammers on hematological factors (blood cell factors and count), including red blood cell indices, mean corpuscular hemoglobin concentration (MCHC), a parameter that measures the concentration of hemoglobin in RBC [13]. Another blood factor is the red blood cell distribution width (RDW-CV) which is the variation of $\mathrm{RBC}$ volume. It is an index of deviation in $\mathrm{RBC}$ size inside blood sampling [14].

\section{Materials and Methods}

The experimental design was approved by the Ethics Committee of the University. 30 male adult Wistar rats, weighing 200-250 g and thirty immature Whistar rats were randomly divided into six groups of 10; including two control groups with any treatment (adult and immature), the sham group exposed to a switched-off jammer device (adults and immature), and experimental group exposed to a switched-on jammer radiation (adult and immature). Sham and experimental groups were kept at the distance of $50 \mathrm{~cm}$ from the jammer antenna. The jammer device used in this study (model MB06) was capable of blocking mobile communications within distance up to 40 meters. In addition, sham (off-condition) $\&$ experimental (on-condition) groups were exposed to electromagnetic fields (EMF) by Mobile Phone Jammers five days a week for forty days. The daily duration of the exposure to radiation was eight hours.

\section{Serological Analysis}

A day after conducting the experiment, blood samples were taken from heart under Anastasia, the serum was separated through centrifugation at $3000 \mathrm{rpm}$ and frozen until used. The number of the platelets, lymphocytes and RBCs were counted and blood factors including Hematocrit, Hemoglobin, MCHC and RDWCV were measured by Sysmex automated $\mathrm{CBC}$ analyzers.

\section{Statistical Analysis}

The data were analyzed by ANOVA followed by Duncan's test. SPSS 16.0 for windows was used to analyze the data. Excel was used to depict the graphs. P-value less than 0.05 was considered as a significant difference.

\section{Results}

The statistical analyses revealed no significant changes in the lymphocyte and WBC counts. The statistical analyses revealed that the exposure to jammer on- (experiment) or off- (sham) radiation in adult rats led to a significant increase in $\mathrm{RBC}(\mathrm{P}=0.001)$ and platelet counts $(\mathrm{P}=0.001$ and 0.02 , respectively) 
compared to control rats. Hematocrit and hemoglobin contents and MCV exhibited a significant increase in jammer-treated animals compared to the control but not with the sham $(\mathrm{P}=0.002, \mathrm{P}=0.001$ and $\mathrm{P}=0.001$, respectively). MCHC was statistically comparable in experimental and sham animals. However, it was shown a significant increase in sham animals compared to that in control rats $(\mathrm{P}=0.014)$. RDWCV showed a significant decrease in jammer-treated animals relative to control $(\mathrm{P}=0.029)$ and a significant increase compared to sham animals $(\mathrm{P}=0.002)$. The values of all data are summarized in Table 1.

In immature rats, RBC, WBC and lymphocyte counts were the same in all groups. Besides, the hemoglobin content and hematocrit did not change significantly by exposure of the rate with jammer on- or off-device. Platelets and MCHCs showed a significant reduction in jammer-treated rats compared with those in both the sham and the control rats $(\mathrm{P}=0.001$ for platelet and $\mathrm{P}=0.015$ and 0.022 for $\mathrm{MCHC}$, respectively). MCV exhibited a significant reduction in experimental rats compared to the sham but not with the control $(\mathrm{P}=0.004)$. RDWCV showed an increase in value in experi- mental group compared to both the control and the sham $(\mathrm{P}=0.001)$. RDWCV also revealed a significant increase in the sham compared with the control as well $(\mathrm{p}=0.001)$. The values of all data are summarized in Table 2.

\section{Discussion}

Literature review demonstrates jammer radiation exerts both beneficial and detrimental effects on different organs. The current study came to the conclusion that turned-on jammer led to an increase in both platelets and RBC, but not WBC, and lymphocyte numbers in mature rats compared to those exposed to turnedoff sham rats. However, up to the best of our knowledge, there are no studies which focus on the influence of turned-on or -off jammer exposure on the number of blood cells in rats. However, the effects of radiofrequency on the blood cell count have been addressed in the past. It has been reported that the exposure of humans to commercial mobile phones for 30 minutes has no influences on lymphocyte count; our data showed the same result with jammer radiation as well [15]. No difference in RBC count has been reported in human exposed to EMF [16] which is in contrast with

Table 1: The effect of electromagnetic fields (EMF) by Mobile Phone Jammers on blood factors in mature rats.

\begin{tabular}{|c|c|c|c|c|c|}
\hline & $\begin{array}{c}\text { Sample } \\
\text { Size }\end{array}$ & $\begin{array}{c}\text { Control } \\
\text { Mean } \pm \text { SD }\end{array}$ & $\begin{array}{c}\text { Sham } \\
\text { Mean } \pm S D\end{array}$ & $\begin{array}{l}\text { Exposed } \\
\text { Mean } \pm S D\end{array}$ & Sig (P-Value) \\
\hline 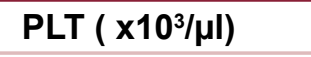 & 10 & $457.50 \pm 251.78 \mathrm{a}$ & $741.10 \pm 128.32 b$ & $740.800 \pm 267.293 b$ & 0.011 \\
\hline MCHC (g/dL) & 10 & $6.83 \pm 31.76 \mathrm{a}$ & $25.94 \pm 19.93 a, b$ & $33.50 \pm 0.95 b$ & 0.029 \\
\hline RDWCV & 10 & $16.55 \pm 0.96 b$ & $14.99 \pm 2.34 a, b$ & $14.44 \pm 1.24 \mathrm{a}$ & 0.021 \\
\hline LYM (cell / $\mu L$ ) & 10 & $84.30 \pm 5.30 \mathrm{a}$ & $83.05 \pm 4.53 \mathrm{a}$ & $84.50 \pm 6.22 \mathrm{a}$ & 0.81 \\
\hline $\mathrm{Hgb}(\mathrm{g} / \mathrm{dL})$ & 10 & $13.92 \pm 1.78 \mathrm{a}$ & $16.17 \pm 0.74 b$ & $15.05 \pm 1.31 \mathrm{a}, \mathrm{b}$ & 0.004 \\
\hline Hct $=(\%)$ & 10 & $44.97 \pm 4.853 \mathrm{a}$ & $50.32 \pm 2.81 \mathrm{~b}$ & $45.01 \pm 4.57 \mathrm{a}$ & 0.011 \\
\hline WBC $\left(10^{3}\right.$ cell/ $\left./ \mu L\right)$ & 10 & $13.42 \pm 6.49 \mathrm{a}$ & $13.39 \pm 3.69 \mathrm{a}$ & $13.20 \pm 3.66 \mathrm{a}$ & 0.994 \\
\hline 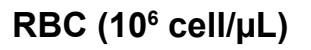 & 10 & $7.30 \pm 0.81 \mathrm{a}$ & $8.58 \pm 0.31 b$ & $7.78 \pm 0.768 a$ & 0.001 \\
\hline
\end{tabular}

$\mathrm{PLT}=$ platelet count $\left(\times 10^{3} / \mu \mathrm{l}\right) ; \mathrm{LYM}=$ lymphocyte count $($ cell $/ \mu \mathrm{L}) ; \mathrm{MCHC}=$ mean corpuscular hemoglobin concentration (g/dL); RDWCV = red blood cell distribution width; $\mathrm{Hgb}=$ hemoglobin; $\mathrm{WBC}=$ white blood cell count; RBC = red blood cell count; $\mathrm{Hct}=(\%$ Hematocrit level $)$ 
Table 2: The effect of electromagnetic fields (EMF) by Mobile Phone Jammers on blood factors in immature rats.

\begin{tabular}{|c|c|c|c|c|c|}
\hline & $\begin{array}{c}\text { Sample } \\
\text { Size }\end{array}$ & $\begin{array}{c}\text { Control } \\
\text { Mean士SD }\end{array}$ & $\begin{array}{c}\text { Sham } \\
\text { Mean } \pm S D\end{array}$ & $\begin{array}{l}\text { Exposed } \\
\text { Mean士SD }\end{array}$ & Sig (P-Value) \\
\hline 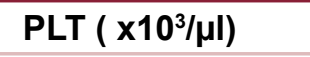 & 10 & $777.30 \pm 266.45 b$ & $721.20 \pm 89.29 b$ & $361.30 \pm 216.35 \mathrm{a}$ & 0.000 \\
\hline MCHC (g/dL) & 10 & $33.49 \pm 1.06 \mathrm{~b}$ & $32.15 \pm 0.60 a, b$ & $11.38 \pm 33.33 \mathrm{a}$ & 0.027 \\
\hline RDWCV & 10 & $13.42 \pm 1.14 \mathrm{a}$ & $12.63 \pm 0.66 \mathrm{a}$ & $18.94 \pm 0.76 b$ & 0.000 \\
\hline LYM (cell $/ \mu L)$ & 10 & $76.48 \pm 9.15 \mathrm{a}$ & $84.77 \pm 3.01 \mathrm{~b}$ & $85.36 \pm 2.70 \mathrm{~b}$ & 0.004 \\
\hline $\mathrm{Hgb}(g / d L)$ & 10 & $15.20 \pm 1.19 a$ & $15.86 \pm 0.66 \mathrm{a}$ & $15.39 \pm 2.16 \mathrm{a}$ & 0.596 \\
\hline Hct $=(\%)$ & 10 & $45.33 \pm 2.53 \mathrm{a}$ & $49.35 \pm 1.49 \mathrm{a}$ & $49.60 \pm 6.32 \mathrm{a}$ & 0.043 \\
\hline WBC $\left(10^{3}\right.$ cell/ $\left./ \mu L\right)$ & 10 & $10.41 \pm 4.61 \mathrm{a}$ & $15.41 \pm 5.53 \mathrm{a}$ & $14.13 \pm 38.87 \mathrm{a}$ & 0.003 \\
\hline RBC (10 $\left.10^{6} \mathrm{cell} / \mu \mathrm{L}\right)$ & 10 & $6.55 \pm 3.07 \mathrm{a}$ & $8.20 \pm 0.30 \mathrm{a}$ & $8.21 \pm 1.04 a$ & 0.093 \\
\hline
\end{tabular}

$\mathrm{PLT}=$ platelet count $\left(\mathrm{x} 10^{3} / \mu \mathrm{l}\right) ; \mathrm{LYM}=$ lymphocyte count $($ cell $/ \mu \mathrm{L}) ; \mathrm{MCHC}=$ mean corpuscular hemoglobin concentration $(\mathrm{g} / \mathrm{dL}) ; \mathrm{RDWCV}=$ red blood cell distribution width; $\mathrm{Hgb}=$ hemoglobin; $\mathrm{WBC}=$ white blood cell count; RBC $=$ red blood cell count; $\mathrm{Hct}=(\%$ Hematocrit level $)$

the result obtained by jammer exposure. There is a contradictory result about the change in platelet count after exposure to EMF. A study demonstrated that the number of platelets was not influenced by 30 minutes of exposure to a smartphone cell [17]. Other reports on rabbits exposure to EMF showed a decrease in the platelet count [18-19]. In young men, exposure to EMF did not lead to any changes in platelet count [20-22]. Our result exhibited jammer usage led to a significant increase in platelet count in turned-on/ jammer respect to the control. The difference in the data might be attributed to the difference in the functional mechanism of two devices (EMF vs. jammer radiation) on blood tissue or different species.

The Current data showed that MCHC increased in the mature group exposed to offjammer device respect to the control group. It has been reported that short- term and longterm exposure of mature rats to ELFEMF had no impact on MCHC [23]. Our result with jammer on-exposed rats confirmed the aforementioned report. Another study reported that higher power of the electromagnetic field exposure $(6 \mathrm{~W})$ to rabbits elevated $\mathrm{MCHC}$ compared to the control group [18]. Our result in jammer-off-exposed rats was along with the aforementioned reports. Such a contradictory result might be due to the nature of the radiation produced by jammer or EMF devices. It seems that jammer radiation neutralized the effects of radiofrequency waves on $\mathrm{MCHC}$.

The results from mature rats prove a significant decrease in RDWCV and increase in hemoglobin content of the group exposed to the on- and off-jammer compared to the control group. In EMF exposed rabbits [18] and young humans [21], hemoglobin content and RDWCV have did not change significantly. Short-term exposure of rats treated with ELFEMF was detected to lead to a decrease in hemoglobin content. However, in long term, it had no significant impacts [23]; we detected that both short-term and longterm exposure of rats to ELFEMF had no influence on RDWCV 23. Our results were in contrast with the results obtained by Cakir et al. and which might be due to the blocking effects of jammer radiation on ELFEMF.

Hematocrit also increased in an on-jammer device exposed rats compared to control conditions. A decrease in hematocrit value was reported previously by treating the rats with 
EMF [24] that is in contrast with our results. Yet, there is a report on human which shows EMF has no significant effects on hematocrit [20-21]. Therefore, it seems that the effect of non-ionizing radiation on blood parameters depends on the species, duration, intensity and the source of radiation.

Blood parameter changes by exposure of immature rats to jammer radiation were different from those in mature ones. For instance, the platelet count reduced in immature rats and it increased in mature rats compared to the control and the sham. In mature rats, RBC revealed an increase in numbers compared to control rats, However, in immature ones, RBC count was the same in all groups. These differences in the effect of jammer radiation might be attributed to different rates of hematopoiesis, the number and differentiation potentials of hematopoietic stem cells in mature and immature rats. Besides, the body water content decreases from neonatal life towards adulthood [25]. The water content of the body influences the penetration rate of EMF radiation [26] and as a result it might modulate its effect on the tissue.

\section{Conclusion}

Based on the results of the present study, it can be concluded that exposure of mature rats to mobile phone jammer radiation caused significant differences in platelets, hematocrit and hemoglobin, $\mathrm{RBC}, \mathrm{MCHC}, \mathrm{MCV}$ and RDWCV compared to the control group. In immature rats, the jammer exposure had no significant effects on hematocrit, hemoglobin as they change in the mature ones. It also modified blood parameters in mature and immature rats in different ways.

\section{Acknowledgment}

The authors wish to thank the Research Deputy of Shiraz University of Medical Sciences. This work was funded by the Ionizing and Non-ionizing Radiation Protection Research Center, Shiraz University of Medical Scienc- es, Iran.

\section{Conflict of Interest}

None Declared

\section{References}

1. Wood AW. Non-ionizing Radiation Protection: Summary of Research and Policy Options. Hoboken: John Wiley \& Sons; 2017.

2. Purohit A, Shukla A, Pandey D, Nishad Y. Mobile Jammer Circuit. International Journal of Research in Science \& Engineering. 2017;3:264-8.

3. Hao D, Yang L, Chen S, Tong J, Tian Y, Su B, et al. Effects of long-term electromagnetic field exposure on spatial learning and memory in rats. Neurol Sci. 2013;34:157-64. doi: 10.1007/s10072-012-09708. PubMed PMID: 22362331.

4. Barsam T, Monazzam MR, Haghdoost AA, Ghotbi MR, Dehghan SF. Effect of extremely low frequency electromagnetic field exposure on sleep quality in high voltage substations. Iranian J Environ Health Sci Eng. 2012;9:15. doi: 10.1186/1735-2746-9-15. PubMed PMID: 23369281; PubMed Central PMCID: PMCPMC3561068.

5. Testylier G, Tonduli L, Malabiau R, Debouzy JC. Effects of exposure to low level radiofrequency fields on acetylcholine release in hippocampus of freely moving rats. Bioelectromagnetics. 2002;23:24955. PubMed PMID: 11948603.

6. Hossmann KA, Hermann DM. Effects of electromagnetic radiation of mobile phones on the central nervous system. Bioelectromagnetics. 2003;24:4962. doi: 10.1002/bem.10068. PubMed PMID: 12483665.

7. Wang Y, Cao ZJ. Radiation from mobile phone and the health. Wei Sheng Yan Jiu. 2006;35:520-3. PubMed PMID: 16986537.

8. Frei P, Poulsen AH, Johansen C, Olsen JH, StedingJessen $M$, Schuz J. Use of mobile phones and risk of brain tumours: update of Danish cohort study. BMJ. 2011;343:d6387. doi: 10.1136/bmj.d6387. PubMed PMID: 22016439; PubMed Central PMCID: PMCPMC3197791.

9. Zmyslony M, Politanski P, Rajkowska E, Szymczak W, Jajte J. Acute exposure to $930 \mathrm{MHz}$ CW electromagnetic radiation in vitro affects reactive oxygen species level in rat lymphocytes treated by iron ions. Bioelectromagnetics. 2004;25:324-8. doi: 10.1002/bem.10191. PubMed PMID: 15197754.

10. Mortavazi S, Habib A, Ganj-Karami A, SamimiDoost R, Pour-Abedi A, Babaie A. Alterations in TSH and Thyroid Hormones following Mobile 
Phone Use. Oman Med J. 2009;24:274-8. doi: 10.5001/omj.2009.56. PubMed PMID: 22216380; PubMed Central PMCID: PMCPMC3243874.

11. Razavinia A, Ahmadi R, Gohari A. The Effects of Mobile Phone Radiation on Serum Levels of Progesterone in Female Rats. 2-3 May 2014. Antalya: International Conference on Chemical, Agricultural and Medical Sciences; 2014. pp. 19-20.

12. Koyu A, Cesur G, Ozguner F, Akdogan M, Mollaoglu $\mathrm{H}$, Ozen $\mathrm{S}$. Effects of $900 \mathrm{MHz}$ electromagnetic field on TSH and thyroid hormones in rats. Toxicol Lett. 2005;157:257-62. doi: 10.1016/j.toxlet.2005.03.006. PubMed PMID: 15917150.

13. Zuckerman K. Approach to the anemias. In: Goldman L, Ausiello D, eritors. Cecil Medicine. 23rd ed. Philadelphia: Saunders Elsevier; 2007.

14. Wen Y. High red blood cell distribution width is closely associated with risk of carotid artery atherosclerosis in patients with hypertension. Exp Clin Cardiol. 2010;15:37-40. PubMed PMID: 20959889; PubMed Central PMCID: PMCPMC2954027.

15. Danese E, Lippi G, Buonocore R, Benati M, Bovo $C$, Bonaguri $C$, et al. Mobile phone radiofrequency exposure has no effect on DNA double strand breaks (DSB) in human lymphocytes. Ann Trans/ Med. 2017;5:272. doi: 10.21037/atm.2017.04.35. PubMed PMID: 28758098; PubMed Central PMCID: PMCPMC5515807.

16. Sajin G, Al D, Savopol T, Roxana M, Eugenia K, editors . $2.45 \mathrm{GHz}$ microwave radiation effects in nonthermal damaging of the human erythrocyte membrane. 4 September 1995. Bolognan: Microwave Conference, 1995 25th European; 1995.

17. Lippi G, Danese E, Brocco G, Gelati M, Salvagno $\mathrm{GL}$, Montagnana M. Acute effects of 30 minutes of exposure to a smartphone call on in vitro platelet function. Blood Transfus. 2017;15:249-53. doi: 10.2450/2016.0327-15. PubMed PMID: 27177410; PubMed Central PMCID: PMCPMC5448831.

18. Sarookhani M, Safari $A$, Zahedpanah M, Rezaei MA, Zaroushani V. Effects of $950 \mathrm{MHz}$ mobile phone electromagnetic fields on the peripheral blood cells of male rabbits. Afr J Pharm Pharmacol. 2012;6:300-4.

19. Alghamdi MS, El-Ghazaly NA. Effects of exposure to electromagnetic field on of some hematological parameters in mice. Open Journal of Medicinal Chemistry. 2012;2:30-42.

20. Dasdag S, Sert C, Akdag Z, Batun S. Effects of extremely low frequency electromagnetic fields on hematologic and immunologic parameters in welders. Arch Med Res. 2002;33:29-32. PubMed PMID: 11825628.

21. Selmaoui B, Bogdan A, Auzeby A, Lambrozo J, Touitou Y. Acute exposure to $50 \mathrm{~Hz}$ magnetic field does not affect hematologic or immunologic functions in healthy young men: a circadian study. Bioelectromagnetics. 1996;17:364-72. doi: 10.1002/(SICI)1521-186X(1996)17:5<364::AIDBEM3>3.0.C0;2-1. PubMed PMID: 8915545.

22. Sayed AG, Rizkallah SS, Lashin YR, Rashed LA. Effect of Pulsed Magnetic Field on Platelets Count and Coagulation Process in Healthy Subjects. International Journal of Therapies and Rehabilitation Research. 2017;6:153-7.

23. Cakir DU, Yokus B, Akdag MZ, Sert C, Mete N. Alterations of hematological variations in rats exposed to extremely low frequency magnetic fields (50 Hz). Arch Med Res. 2009;40:352-6. doi: 10.1016/j.arcmed.2009.07.001. PubMed PMID: 19766897.

24. Aziz IA, El-Khozondar HJ, Shabat M, Elwasife K, Mohamed-Osman A. Effect of electromagnetic field on body weight and blood indices in albino rats and the therapeutic action of vitamin C or E. Romanian Journal of Biophysics. 2010;20:235-44.

25. Friis-Hansen B. Body water compartments in children: changes during growth and related changes in body composition. Pediatrics. 1961;28:169-81. PubMed PMID: 13702099.

26. Miklavcic D, Pavšelj N, Hart FX. Electric properties of tissues. New Jersey : John Wiley \& Sons; 2006. 